\title{
UPAYA MENINGKATKAN PRESTASI BELAJAR MATEMATIKA DENGAN MENGGUNAKAN ALAT PERAGA PADA SISWA KELAS IV A SD NEGERI PAJAMBON KECAMATAN KRAMATMULYA KABUPATEN KUNINGAN
}

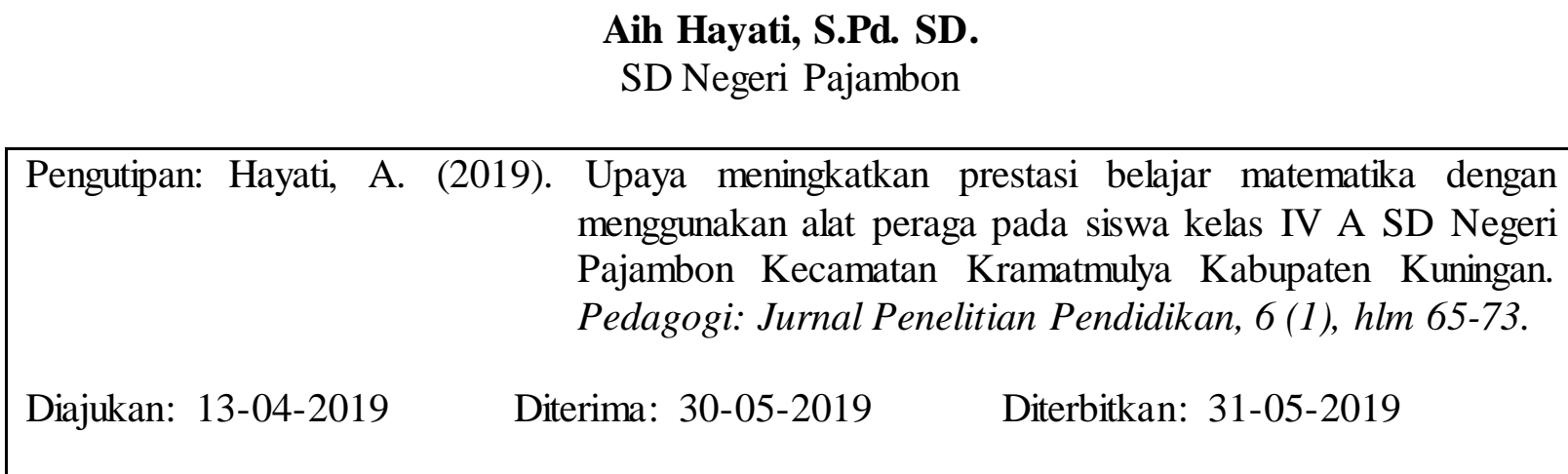

\begin{abstract}
ABSTRAK
Tujuan penelitian yang akan dicapai adalah untuk mengetahui meningkatnya prestasi belajar matematika pada aspek bilangan pecahan dalam pembelajaran dengan menggunakan alat peraga pada siswa kelas IV A SD Negeri Pajambon Kecamatan Kramatmulya Kabupaten Kuningan tahun pelajaran 2017/2018. Bentuk penelitian ini berupa Penelitian Tindakan Kelas ( PTK ) yang dilaksanakan dalam dua siklus perbaikan. Subjek penelitian ini adalah siswa kelas IV A SD Negeri Pajambon Kecamatan Kramatmulya Kabupaten Kuningan tahun 2017 pada pelajaran Matematika dengan jumlah populasi siswa sebanyak 23 orang. Teknik pengumpulan data dalam penelitian ini dilakukan melalui kegiatan berupa: (a) perencanaan tindakan; (b) pelaksanaan tindakan; (c) pengamatan tindakan; dan (d) refleksi. Hasil penelitian menunjukkan adanya peningkatan nilai rata-rata 48,70 dari pra siklus, 55,7 pada siklus 1 pertemuan $1,62,6$ pada siklus 1 pertemuan 2 dan 72,6 pada siklus 2 pertemuan 1, 81,7 pada siklus 2 pertemuan 2. Sementara dari prosesntasi ketuntasan terjadi peningkatan dari $26 \%$ pada pertemuan 1 Siklus I, menjadi $43 \%$ pada pertemuan 2 Siklus 1, Menjadi $78 \%$ pada petemuan 1 Siklus II dan menjadi $87 \%$ pada pertemuan 2. Dari data hasil diatas maka nilai dan ketuntasan selalu mengalami peningkatan pada tiap siklusnya. Sehingga dapat disimpukan sebagai berikut: melalui alat peraga dapat meningkatkan prestasi belajar matematika pada siswa kelas IV A SD Negeri Pajambon Kecamatan Kramatmulya Kabupaten Kuningan Tahun pelajaran 2017/2018.
\end{abstract}

Kata kunci: Prestasi Belajar, Alat Peraga 
Aih Hayati, S.Pd. SD.

Upaya Meningkatkan Prestasi Belajar Matematika dengan Menggunakan Alat Peraga pada

Siswa Kelas IV A SD Negeri Pajambon Kecamatan Kramatmulya Kabupaten Kuningan

\section{PENDAHULUAN}

Sekolah menjadi salah satu tempat berlangsungnya kegiatan belajar mengajar yang khusus menjadi tanggung jawab guru. Mengenai sistem pendidikan didasarkan pada lamanya jangka waktu seseorang mencapai kedewasaannya, hal ini nampak jelas dengan penyelenggara sekolah secara bertingkat dan proses belajar mengajarnya dalam bentuk klasikal. Sedangkan isi pendidikan ini dituangkan dalam bentuk kurikulum. Hal ini tentunya disesuaikan dengan kemajuan dan perkembangan masyarakat.

Mengingat bahwa metode adalah cara yang dalam fungsinya merupakan suatu alat untuk mencapai tujuan, maka makin baik metode itu makin efektif pula pencapaian tujuan. Sehingga dapat dikatakan bahwa apabila guru dalam memilih metode mengajar tepat dan dilaksanakan sesuai dengan prosedur, diharapkan siswa dapat menerima dan memahami dengan baik apa yang diajarkan oleh guru.

Pada saat proses pembelajaran di kelas IVA dengan mata pelajaran matematika tentang pecahan dengan memakai metode ceramah, media tulisan guru di papan tulis dengan materi menceritakan kegiatan sehari-hari sebelum berangkat ke sekolah. Pada kegiatan inti: guru menjelaskan materi siswa mendengarkan. Guru mengadakan tanya jawab, sebagian siswa belum ada yang bertanya. Pada kegiatan akhir guru mengadakan penilaian untuk mengetahui kemampuan siswa dalam belajar dengan hasil sebagai berikut: Nilai tertinggi 80; nilai terendah 30 dan rata-rata nilai 55,7 .

Melihat realita di atas maka guru perlu melaksanakan perbaikan sistem pembelajaran. Selama ini pembelajaran yang dilaksanakan tanpa menggunakan alat peraga kurang menarik perhatian siswa, sehingga prestasi belajar siswa. Selain itu dari berbagai sumber dijelaskan bahwa cara pembelajaran dengan menggunakan alat peraga dapat meningkatkan minat belajar siswa sehingga diharapkan prestasi belajar dapat memuaskan. Untuk mengetahui benar tidaknya penggunaan alat peraga dapat meningkatkan prestasi belajar matematika maka perlu diadakan penelitian.

\section{METODE PENELITIAN}

Dalam penelitian ini menggunakan model yang didasarkan atas konsep pokok bahwa penelitian tindakan terdiri dari empat komponen pokok yang juga menunjukkan langkah pelaksanaan penelitian, yaitu: 1. Perencanaan atau Planning 2. Tindakan atau Acting3. Pengamatan atau Observasing dan Refleksi atau Reflekting (Arikunto, 2002: 83). Dimana dari empat hal tersebut dapat diilustrasikan dengan bagan gambar berikut.

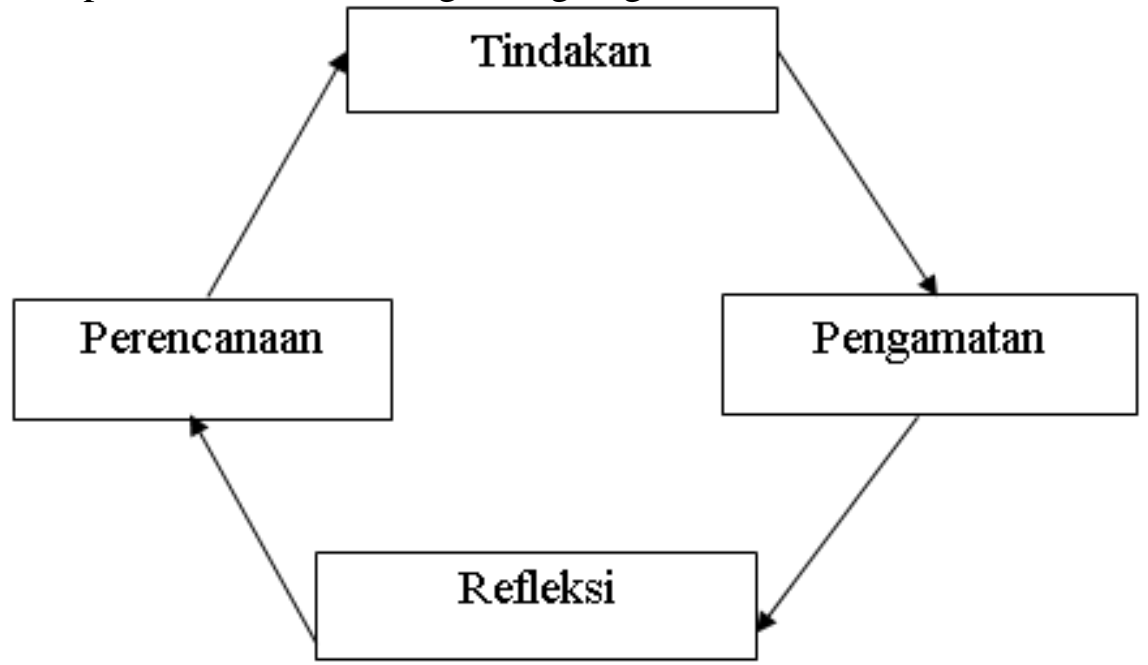

Gambar 1. Fase Penelitian Tindakan Kelas secara Ringkas 


\section{HASIL PENELITIAN DAN PEMBAHASAN}

Dari hasil ulangan harian sebelum kegiatan perbaikan pembelajaran dapat diketahui hasilnya sebagai berikut: Dari 23 siswa yang mengikuti pembelajaran matematika dapat diketahui nilai tertinggi yang diraih siswa adalah 80 dan yang terendah adalah 30 , dengan ratarata hasil ulangan harian adalah 55,7. Adapun data lengkap perolehan nilai siswa pada siklus I dapat dilihat pada tabel berikut.

Tabel 1. Rekapitulasi Hasil Belajar Siklus I pada Pertemuan 1

\begin{tabular}{cccc}
\hline Nomor & Nilai & Frekuensi & Prosentase \\
\hline $\mathbf{1}$ & 30 & 3 & $13,04 \%$ \\
\hline $\mathbf{2 .}$ & 40 & 2 & $8,69 \%$ \\
\hline $\mathbf{3 .}$ & 50 & 5 & $21,74 \%$ \\
\hline $\mathbf{4 .}$ & 60 & 7 & $30,43 \%$ \\
\hline $\mathbf{5 .}$ & 70 & 4 & $17,39 \%$ \\
\hline $\mathbf{6 .}$ & 80 & 2 & $8,7 \%$ \\
\hline \multicolumn{6}{r}{} & Jumlah & 23 & $100 \%$ \\
\hline
\end{tabular}

Dari data dalam tabel di atas bila dibuat dalam bentuk diagram sebagai berikut.

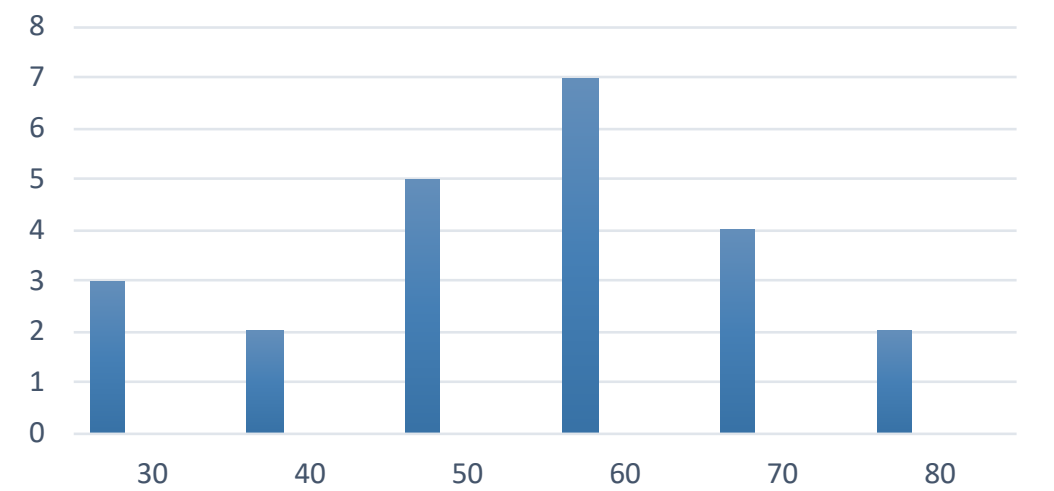

Gambar 1. Histogram Prestasi Belajar Matematika Siklus I

Setelah selesainya siklus 1 maka siswa dites dengan soal formatif dengan hasil tes sebagai berikut: Dari 23 siswa yang mengikuti pembelajaran matematika dapat diketahui nilai tertinggi yang diraih siswa adalah 80 dan yang terendah adalah 40, dengan rata-rata hasil ulangan test formatif adalah 62,6. Adapun data lengkap peroleh nilai oleh siswa pada siklus I dapat dilihat pada tabel beriku.

Tabel 2. Rekapitulasi Hasil Belajar Siklus I pada Pertemuan 2

\begin{tabular}{cccc}
\hline Nomor & Nilai & Frekuensi & Prosentase \\
\hline $\mathbf{1}$ & 40 & 3 & $13,04 \%$ \\
\hline $\mathbf{2 .}$ & 50 & 2 & $21,74 \%$ \\
\hline $\mathbf{3 .}$ & 60 & 8 & $34,78 \%$ \\
\hline $\mathbf{4 .}$ & 70 & 7 & $30,43 \%$ \\
\hline $\mathbf{5 .}$ & 80 & 1 & $4,35 \%$ \\
\hline $\mathbf{6 .}$ & 90 & 2 & $8,7 \%$ \\
\hline \multicolumn{6}{r}{ Jumlah } & 23 & $100 \%$ \\
\hline
\end{tabular}


Aih Hayati, S.Pd. SD.

Upaya Meningkatkan Prestasi Belajar Matematika dengan Menggunakan Alat Peraga pada

Siswa Kelas IV A SD Negeri Pajambon Kecamatan Kramatmulya Kabupaten Kuningan

Dari data dalam tabel 2 di atas bila dibuat dalam bentuk diagram sebagai berikut.

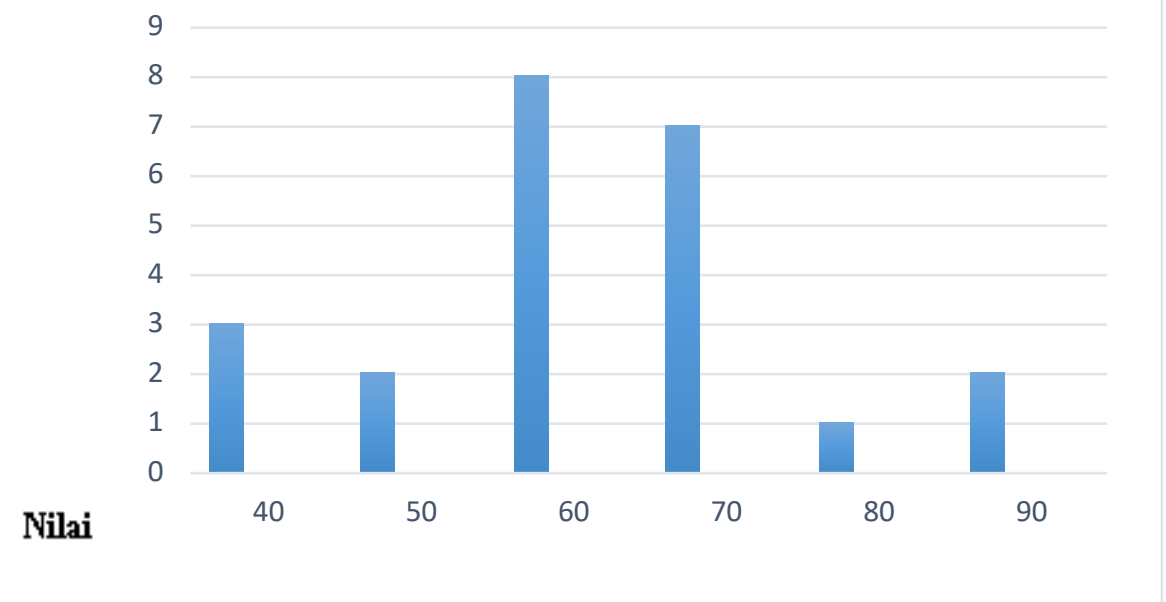

Gambar 2. Histogram Prestasi Belajar Matematika Pada Siklus I

Masalah yang muncul dalam pembelajaran siklus 1 dapat dilihat oleh peneliti saat berlangsungnya proses pembelajaran dan hasil test formatif yang dilakukan setelah selesai pembelajaran. Adapun masalah yang timbul dalam pembelajaran siklus I antara lain: (a) Keaktifan dalam mengikuti pembelajaran dirasa kurang; (b) Kemampuan anak untuk menyelesaikan tugas atau ulangan soal cerita kurang karena kemampuan anak dalam memahami kata-kata dirasa kurang, apalagi dengan model soal yang memadukan berbagai jenis bahan contoh yang berbeda-beda; (c) Ketrampilan bertanya dirasakan kurang karena anak masih sukar memahami konsep bilangan pencahan; (d) Kemampuan mengemukakan pendapat masih dirasa kurang baik.

Rancangan Strategi penyelesaian masalah dan paparan langkah implementasi penyelesaian dalam siklus 1: (a) Untuk mengaktifkan anak-anak yang kurang aktif dapat dilakukan dalam pembelajaran siklus II dengan menyusun lembar kerja yang membuat setiap anggota kelompok menjadi aktif; (b) Untuk meningkatkan kemampuan anak menyelesaikan soal cerita ,maka pada siklus dibuat dengan variasi soal yang mudah dipahami oleh anak agar anak mampu memahami soal cerita dengan baik; (c) Agar anak dapat memiliki kemampuan bertanya dengan baik maka pada siklus II guru akan membuat lembar kerja yang memungkinkan anak lebih aktif lagi. Selain itu pada siklus 1 jumlah kelompok terasa terlalu banyak yakni 6 orang sehingga ada sebagian anak kurang terlibat dalam proses diskusi dalam kelompok maka pada siklus II jumlah anggota kelompok diperkecil menjadi 4 orang siswa dan setiap kelompok diberi kesempatan untuk menyampaikan hasil diskusi di depan kelas; (d) Agar dapat membangkitkan kemampuan mengemukakan pendapat siswa maka pada siklus II guru akan memberikan tugas dan pertanyaan pada siswa yang dirasa kurang aktif pada siklus 1 .

Hasil pembelajaran siklus II pertemuan 1 sebagai berikut: pada saat tes pembelajaran matematika dapat diketahui nilai tertinggi yang diraih siswa adalah 100 dan yang terendah adalah 50, dengan rata-rata hasil ulangan test formatif adalah 72,6. Adapun data lengkap perolehan siswa pada tabel berikut.

Tabel 3. Rekapitulasi Hasil Belajar Pada Siklus II Pertemuan 1

\begin{tabular}{cccc}
\hline Nomor & Nilai & Frekuensi & Prosentase \\
\hline $\mathbf{1}$ & 50 & 2 & $8,7 \%$ \\
\hline $\mathbf{2}$ & 60 & 3 & $13,04 \%$ \\
\hline $\mathbf{3}$ & 70 & 9 & $39,13 \%$ \\
\hline $\mathbf{4}$ & 80 & 6 & $26,08 \%$ \\
\hline $\mathbf{5}$ & 90 & 2 & $8,7 \%$ \\
\hline
\end{tabular}




\begin{tabular}{cccc}
\hline $\mathbf{6}$ & 100 & 1 & $4,35 \%$ \\
\hline & Jumlah & 23 & $100 \%$ \\
\hline
\end{tabular}

Dari data dalam tabel 3 di atas bila dibuat dalam bentuk diagram sebagai berikut.

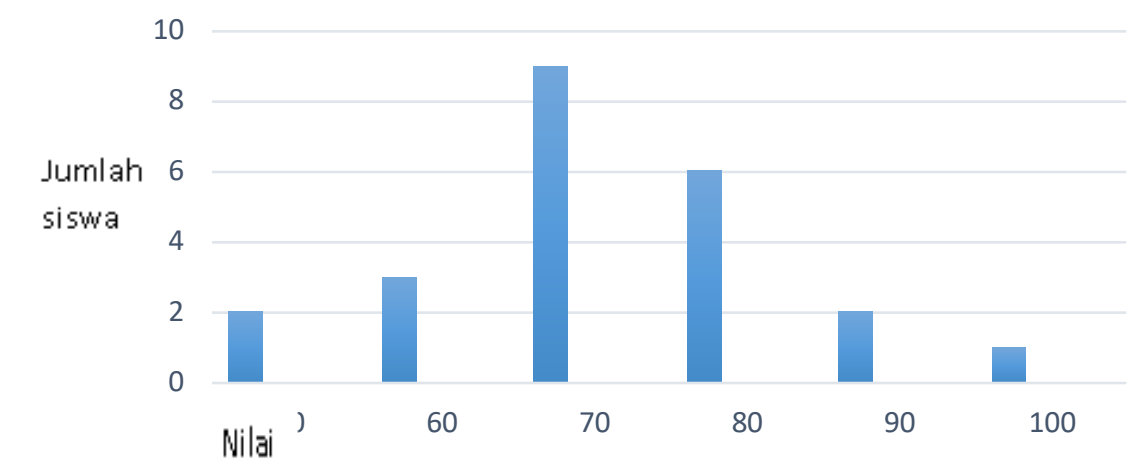

Gambar 3. Histogram Prestasi Belajar Matematika pada Siklus II Pertemuan 1

Setelah selesainya siklus II pertemuan 2, maka siswa dites dengan soal formatif dengan hasil tes sebagai berikut: Dari 23 siswa yang mengikuti pembelajaran matematika dapat diketahui nilai tertinggi yang diraih siswa adalah 100 dan yang terendah adalah 60, dengan rata-rata hasil ulangan test formatif adalah 81,7. Adapun data lengkap peroleh nilai oleh siswa pada siklus I dapat dilihat pada tabel berikut:

Tabel 4. Rekapitulasi Hasil Belajar Pada Siklus II Pertemuan 2

\begin{tabular}{cccc}
\hline Nomor & Nilai & Frekuensi & Prosentase \\
\hline $\mathbf{1}$ & 60 & 3 & $13,04 \%$ \\
\hline $\mathbf{2}$ & 70 & 2 & $8,7 \%$ \\
\hline $\mathbf{3}$ & 80 & 9 & $39,13 \%$ \\
\hline $\mathbf{4}$ & 90 & 6 & $26,08 \%$ \\
\hline $\mathbf{5}$ & 100 & 3 & $13,04 \%$ \\
\hline & Jumlah & 23 & $100 \%$ \\
\hline
\end{tabular}

Dari data dalam tabel 4 di atas bila dibuat dalam bentuk diagram sebagai berikut.

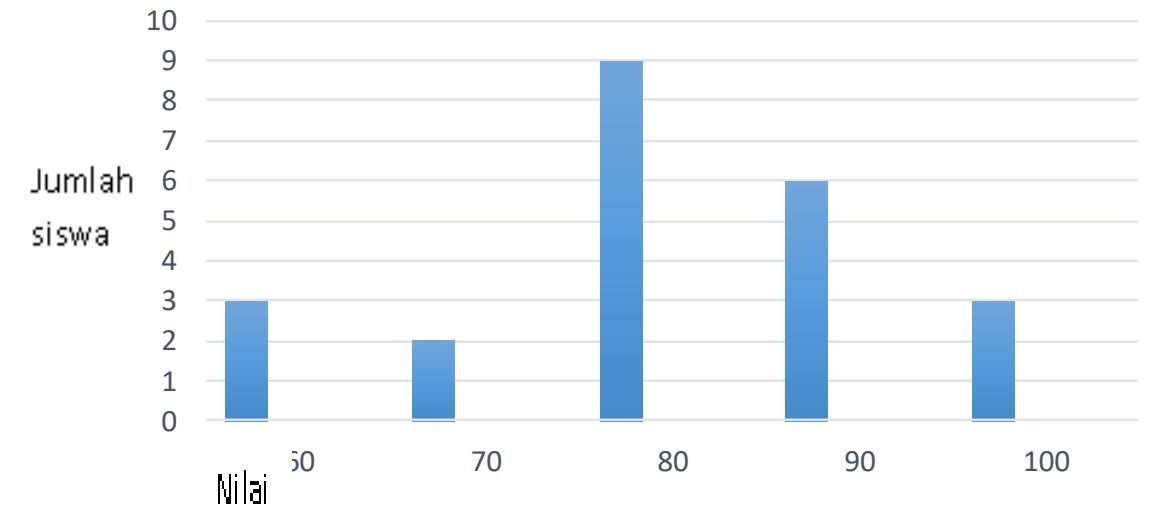

Gambar 4. Histogram Prestasi Belajar Matematika pada Siklus II pertemuan 2

Sedangkan untuk batas tuntas pelajaran matematika (KKM) siswa kelas IVA di SD Negeri Pajambon adalah 70 sehingga siswa yang dinyatakan tuntas belajar matematika setelah siklus II pertemuan 2 adalah 20 siswa dari 23 siswa $(86,95 \%)$, karena presentase 
Aih Hayati, S.Pd. SD.

Upaya Meningkatkan Prestasi Belajar Matematika dengan Menggunakan Alat Peraga pada

Siswa Kelas IV A SD Negeri Pajambon Kecamatan Kramatmulya Kabupaten Kuningan

ketuntasan kelas $86,95 \%$ sehingga dapat dikatakan siswa dikelas IVA memperoleh ketuntasan kelas secara klasikal.

Pada pembelajaran siklus 2 permasalahan yang muncul tidak begitu berarti artinya hampir semua anak telah mengikuti pembelajaran dengan baik perihal keaktifan dalam proses belajar mengajar serta keaktifan bertanya pada guru sudah mulai tumbuh dengan baik. Perihal kemampuan anak mamahami materi soal cerita sudah membaik karena soal telah dibuat secara bahasa sederhana dan mengacu pada pengalaman siswa sehari-hari karena permasalahan dalam siklus 2 kurang begitu berarti maka perlu adanya langkah-langkah penyelesaian masalah. Dalam hal ini perlu disampaikan adanya saran kepada peneliti lain bahwa untuk meningkatkan kemampuan matematika anak pada pokok bahasan pecahan, dapat dilakukan dengan metode belajar kelompok dengan media konkret. Dari pembahasan tersebut dapat dibuat suatu perbandingan antara sebelum Silus I, Siklus I, dan Siklus II pada tabel sebagai berikut.

Tabel 5. Perbandingan Prestasi Matematika Siswa Kelas IV

\begin{tabular}{cccccc}
\hline No & Uraian & \multicolumn{2}{c}{ Siklus I } & \multicolumn{2}{c}{ Siklus II } \\
\cline { 3 - 6 } & & Pertemuan & Pertemuan & Pertemuan & Pertemuan \\
& & 1 & 2 & 1 & 2 \\
\hline $\mathbf{1}$ & Nilai 30 & 3 siswa & - siswa & - siswa & - siswa \\
\hline $\mathbf{2}$ & Nilai 40 & 2 Siswa & 3 Siswa & - Siswa & - Siswa \\
\hline $\mathbf{3}$ & Nilai 50 & 5 siswa & 2 siswa & 2 siswa & - siswa \\
\hline $\mathbf{4}$ & Nilai 60 & 7 siswa & 8 siswa & 3 siswa & 3 siswa \\
\hline $\mathbf{5}$ & Nilai 70 & 4 siswa & 7 siswa & 9 siswa & 2 siswa \\
\hline $\mathbf{6}$ & Nilai 80 & 2 siswa & 1 siswa & 6 siswa & 9 siswa \\
\hline $\mathbf{7}$ & Nilai 90 & - siswa & 2 siswa & 2 siswa & 6 siswa \\
\hline $\mathbf{8}$ & Nilai 100 & - siswa & - siswa & 1 siswa & 3 siswa \\
\hline $\mathbf{9}$ & Nilai Rata-rata & 55,7 & 62,6 & 72,6 & 81,7 \\
\hline $\mathbf{1 0}$ & Siswa Tuntas & 6 siswa & 10 siswa & 18 siswa & 20 siswa \\
\hline $\mathbf{1 1}$ & Prosentase Siswa Tuntas & $26 \%$ & $43 \%$ & $78 \%$ & $86,95 \%$ \\
\hline $\mathbf{1 2}$ & Siswa Tak Tuntas & 17 siswa & 13 siswa & 5 siswa & 2 siswa \\
\hline $\mathbf{1 1}$ & Prosentase Siswa Tak & $73,9 \%$ & $56,52 \%$ & $21,74 \%$ & $8,7 \%$ \\
& Tuntas & & & & \\
\hline
\end{tabular}

Dari tabel di atas dapat dibuat diagram sebagai berikut.

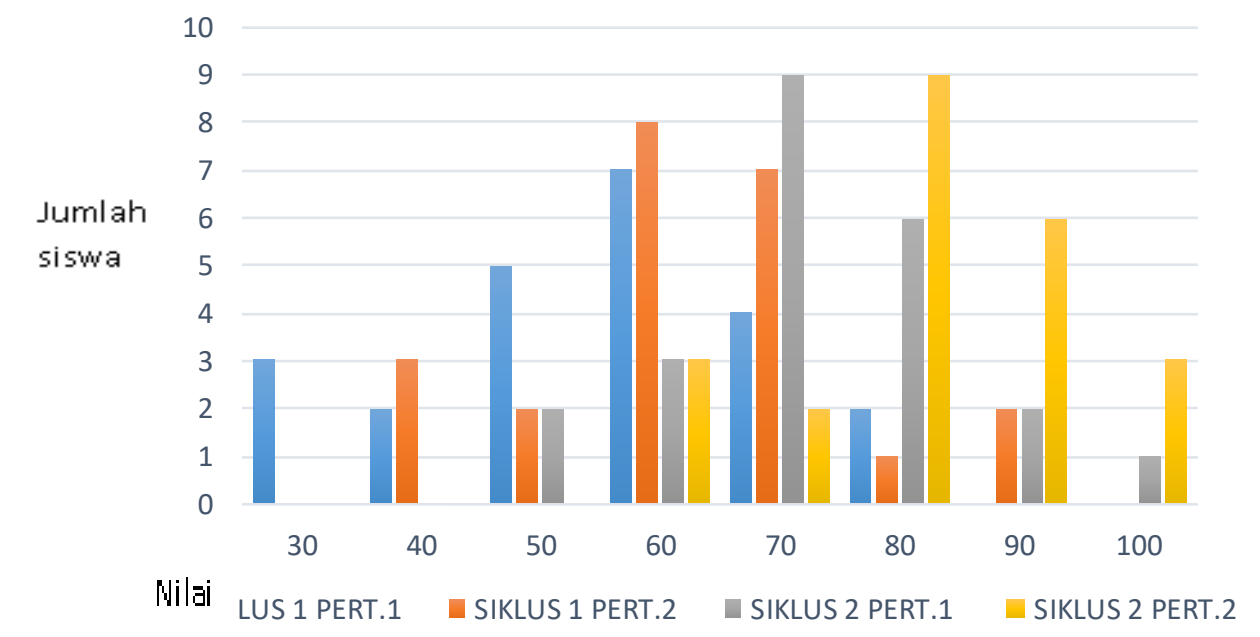

Gambar 5. Histogram Perbandingan Prestasi Belajar Matematika pada SiklusI Pertemuan 1 dan 2, Siklus II pertemuan 1 dan 2 


\section{Pembahasan}

Pembahasan dari Siklus I Pertemuan 1; Rata - rata yang diperoleh siswa sebesar 55,7. 2) Siswa yang mendapatkan nilai 70 ke atas sebanyak 4 orang. 2) Siswa yang mendapatkan nilai antara 60 sampai 69 sebanyak 7 orang. 3) Siswa yang mendapatkan nilai kurang dari 60 sebanyak 10 orang. 4) Siswa yang telah dinyatakan memiliki ketuntasan belajar (dengan nilai 70 ke atas ) sebanyak 2 orang dari jumlah 23 siswa atau $26 \%$, sedangkan anak yang belum tuntas sebanyak 17 orang dari jumlah 23 siswa atau 73,9\%.

Pembahasan dari Siklus I Pertemuan 2; Rata - rata yang diperoleh siswa sebesar 62,6.2) Siswa yang mendapatkan nilai 70 ke atas sebanyak 10 orang. 3) Siswa yang mendapatkan nilai antara 60 sampai 69 sebanyak 8 orang. 4) Siswa yang mendapatkan nilai kurang dari 60 sebanyak 5 orang. 5) Siswa yang telah dinyatakan memiliki ketuntasan belajar (dengan nilai $70 \mathrm{ke}$ atas ) sebanyak 10 orang dari jumlah 23 siswa atau $43 \%$, sedangkan anak yang belum tuntas sebanyak 13 orang dari jumlah 23 siswa atau 56,52\%.

Pembahasan dari Siklus II Pertemuan 1; Rata - rata yang diperoleh siswa sebesar 72,6.. 2) Siswa yang mendapatkan nilai 70 ke atas sebanyak 18 orang. 3) Siswa yang mendapatkan nilai antara 60 sampai 69 sebanyak 3 orang. 4) Siswa yang mendapatkan nilai kurang dari 60 sebanyak 2 orang. 5) Siswa yang telah dinyatakan memiliki ketuntasan belajar (dengan nilai 70 ke atas ) sebanyak 18 orang dari jumlah 23 siswa atau $78 \%$, sedangkan anak yang belum tuntas sebanyak 5 orang dari jumlah 23 siswa atau 21,74\%.

Pembahasan dari Siklus II Pertemuan 2; Rata - rata yang diperoleh siswa sebesar 81,7. 2) Siswa yang mendapatkan nilai $70 \mathrm{ke}$ atas sebanyak 20 orang 3) Siswa yang mendapatkan nilai antara 60 sampai 69 sebanyak 3 orang. 4) Siswa yang mendapatkan nilai kurang dari 60 sebanyak-orang. 5) Siswa yang telah dinyatakan memiliki ketuntasan belajar (dengan nilai 70 ke atas ) sebanyak 230 orang dari jumlah 23 siswa atau 86,95\%, sedangkan anak yang belum tuntas sebanyak 3 orang dari jumlah 23 siswa atau 8,7\%.

Pembahasan hasil Analisis Data; Setelah melakukan dan menyelesaikan pembelajaran dengan menggunakan alat peraga nampak bahwa hasil klasikal dari nilai pre tes sebelum pembelajaran dengan alat peraga jika dilihat dari nilai rata-rata kelas memang sudah kurang baik yaitu dapat dilihat bahwa rata-rata nilai 55,7 dan rata-rata nilai harian setelah mendapat pembelajaran dengan alat peraga mencapai 62,6. Lagi pula jika dicermati lebih mendalam pada hitungan di atas nampak bahwa ada sebanyak 23 siswa dari 23 siswa atau 86,95\% siswa pada siklus II yang mendapatkan nilai post tes lebih dari 70 .

Hal ini berarti bahwa dari segi ketuntasan belajar (disini digunakan kriteria tuntas belajar jika siswa mendapatkan nilai 70 atau lebih). Disisi lain dapat dilihat bahwa dengan adanya pembelajaran dengan menggunakan alat peraga ternyata telah memacu siswa untuk lebih giat belajar . Dari uraian tersebut di atas dapat disimpulkan bahwa pembelajaran dengan menggunakan alat peraga pada pembelajaran matematika di kelas IVA SD Negeri Pajambon Kecamatan Kramatmulya Kabupaten Kuningan meningkat hasil belajarnya.

\section{SIMPULAN DAN SARAN}

Berdasarkan hasil dan pembahasan dalam dalam Bab IV A dapat diketahui bahwa: (a) Nilai rata prestasi belajar Matematika siswa kelas IV A pada siklus I pertemuan 1 sebesar 55,7, pada siklus I pertemuan 2 sebesar 62,6, pada siklus II pertemuan 1 sebesar 72,6 dan pada siklus II pertemuan 2 sebesar 81,7 sehingga terdapat kenaikan nilai rata - rata dari siklus I ke siklus II; (b) Prosentase ketuntasan belajar siswa pada siklus I pertemuan 1 menunjukkan angka sebesar 26\% ( 6 siswa tuntas dalam belajarnya dari seluruh peserta 23 siswa), pada siklus I pertemuan 2 menunjukkan angka sebesar 43\% ( 10 siswa tuntas dalam belajarnya dari seluruh peserta 23 siswa), pada siklus II pertemuan 1 sebesar $78 \%$ (18 siswa tuntas dalam belajarnyadari seluruh peserta 23 siswa) dan pada siklus II pertemuan 2 sebesar 86,95 \% (20 siswa tuntas dalam belajarnya dari seluruh peserta 23 siswa). Dengan demikian terdapat 
Aih Hayati, S.Pd. SD.

Upaya Meningkatkan Prestasi Belajar Matematika dengan Menggunakan Alat Peraga pada Siswa Kelas IV A SD Negeri Pajambon Kecamatan Kramatmulya Kabupaten Kuningan

peningkatan ketuntasan belajar siswa dari siklus I ke siklus II. Berdasarkan keterangan di atas maka dapat dibuat suatu kesimpulan sebagai berikut: Melalui alat peraga dapat meningkatan prestasi belajar matematikapada siswa kelas IV A SD Negeri pajambon tahun pelajaran 2017 / 2018. 


\section{DAFTAR PUSTAKA}

Hera lestari Mikarsa, dkk. (2007). Pendidikan anak di SD tentang teori-teori belajar. Jakarta: Universitas Terbuka.

Mulya Sumantri, dkk. (2007). Perkembangan peserta didik. Jakarta:Universitas Terbuka.

Nurdin, dkk. (1999). Matematika untuk SD Kelas IV. Bandung: Rosdakarya.

Nur Fajariyah dan Defi Triratnawati. (2008). Cerdas berhitung matematika. Jakarta: Pusat Perbukuan Departemen Pendidikan Nasional

Peraturan Menteri Pendidikan Nasional Nomor 34 Tahun 2008 tentang Penetapan Buku Teks Pelajaran Matematika.

Suciati, dkk. (2007).Belajar dan pembelajaran 2. Jakarta: Universitas Terbuka.

UU RI Nomor 20 Tahun 2003 tentang Sistem Pendidikan Nasional. Jakarta: DPR RI.

Wardani,,I. G. A. K., dkk. (2006). Penelitian Tindakan Kelas.Jakarta : Universitas Terbuka http://www.zonareferensi.com/pengertian-belajar/

http://www.definisipengertian.com/2015/definisi-dan-pengertian-mengajar.html http://metodepembelajaran10.blogspot.com/2017/01/pengertian-dan-pola-pikir-kurikulum2013.html 